\title{
Structural and optical properties Investigation of ZnxCd1-xS thin films
}

\begin{abstract}
Nada K. Abbas ${ }^{1}$, Ahlam M.Farhan ${ }^{2}$ Naan F. Majeed ${ }^{1}$ and Suaad A-Muhameed ${ }^{1}$ 1Department of Physics College of Science for Women, Baghdad University, Baghdad. Iraq E-mail: nadabbs@yahoo.com

2 Department of Chemistry College of Science for Women, Baghdad University, Baghdad. Iraq ahlam63a@yahoo.com

1Department of Physics College of Science for Women, Baghdad University, Baghdad. Iraq neean89@yahoo.com

Abstract - CdZn $\mathrm{S}_{1-\mathrm{X}}$ thin films with different composition have been deposited on glass substrate by by the spray pyrolysis method at RT using $\mathrm{CdCl}_{2}(0.1 \mathrm{M}), \mathrm{ZnCl}_{2}(0.1 \mathrm{M})$ and $\mathrm{H}_{2} \mathrm{NCSNH}_{2}(0.1 \mathrm{M})$ solution and a substrate temperature of $\left(400 \pm 20^{\circ} \mathrm{C}\right)$. X-ray diffraction studies reveal that the films are polycrystalline in nature with hexagonal structure and preferential orientation along (002). The grain size of the films is found to increase form (37.397 to 46.902) $\mathrm{nm}$ with increasing Zinc concentration while the strain and the dislocation density of the films are found to decrease from ( 7.15 to 4.54$) \times 10^{4}$ rad and from (3.82 to 1.93) $\times 10^{14}$ lines. $\mathrm{m}^{-2}$ respectively. The transmittance spectrums of $\mathrm{CdZn}_{x} \mathrm{~S}_{1-\mathrm{x}}$ thin films reveal very pronounced interference effects for photon energies below the fundamental absorption edge by exhibiting interference pattern. The optical energy gap for $\mathrm{CdZn}_{x} \mathrm{~S}_{1-\mathrm{x}}$ thin films increases and shifts towards the UV region as the $\mathrm{Zn}$ concentration in the films increased.
\end{abstract}

Keywords: $C d Z n_{x} S_{1-x}$ thin films, CdS thin films , ZnS thin films, spray pyrolysis technique

\section{Council for Innovative Research}

Peer Review Research Publishing System

\section{Journal: Journal of Advances in Chemistry}

Vol. 12 , No. 3

www.cirworld.com, editor@cirworld.com 


\section{Introduction}

Recent investigations have evoked considerable interest in ZnS thin films due to their vast potential for use in thin film devices such as photo luminescent and electroluminescent devices and more recently as $n$-type window layer hetero junction solar cells [1].Zinc sulfide has found wide use as a thin film coating in the optical and microelectronic industries. It has high refractive index $(2 \times 25$ at $632 \mathrm{~nm})$, high effective dielectric constant ( 9 at $1 \mathrm{MHz})$ and wide wavelength pass band $(0 \times 4-13 \mathrm{~mm})$ [2]. It is commonly used as filter, reflector and planar waveguide.

Cadmium sulphide (CdS) are considered to be very important materials for a wide spectrum of optoelectronic applications as having good chemical , mechanical stability [3] and specific physical properties such as direct band gap widths, high absorption coefficients in the visible and infrared part of the solar spectrum, good electrical properties (e.g. carrier mobility and lifetime) and increased capability in obtaining adjustable $n$ - or p-type conductivity by doping [4]

Thin film of $\mathrm{Zn}_{\mathrm{x}} \mathrm{Cd}_{1-\mathrm{x}} \mathrm{S}$ are known to have properties in between those of CdS and ZnS .Because The addition of Zinc to cadmium sulphide has resulted in very interesting properties related to photo electrochemistry and optoelectronics [5] , because the ternary materials provide a possibility of tailoring their properties as per requirements and hence project themselves as important semiconducting materials for the applications in the field of device fabrication [6] . The band gap energy of CdS can be increased by the addition of $\mathrm{ZnS} \quad(\mathrm{Eg}=3.6 \mathrm{eV})$. The ternary compound $\mathrm{Zn}_{\mathrm{x}} \mathrm{Cd}_{1-\mathrm{x}} \mathrm{S}$ offers a great range of tune ability both of its band gap (from 2.42eV for CdS to $3.6 \mathrm{eV}$ for $\mathrm{ZnS}$ ) and its lattice parameters[7].Several techniques were employed for the growth of the ternary $\mathrm{CdZnS}$ films. In the present work, $Z \mathrm{n}_{x} \mathrm{Cd}_{1-\mathrm{x}} \mathrm{S}$ thin films were deposited by Spray pyrilysis technique at different composition of $(x)$. The effect of Zinc concentration on the structural and optical properties of these films was studied and discussed.

\section{Experimental Details}

$\mathrm{Zn} x \mathrm{Cd} 1-x \mathrm{~S}$ thin films were produced on a glass substrate by the spray pyrolysis technique . The $\mathrm{ZnCl} \mathrm{CdCl}_{2}$ salts and $\mathrm{H} 2 \mathrm{NCSNH} 2$ were dissolved in deionized water in separate beakers . Aqueous solutions of $\mathrm{ZnCl}_{2}, \mathrm{CdCl}_{2}$ salts and $\mathrm{H} 2 \mathrm{NCSNH} 2$ were used as the sources of $\mathrm{Zn}, \mathrm{Cd}$,S, respectively. The $\mathrm{ZnCl}_{2}, \mathrm{CdCl}_{2}$ and $\mathrm{H} 2 \mathrm{NCSNH} 2$ solutions were mixed for $30 \mathrm{~min}$. With a magnetic stirrer. The compositions of the solutions used to fabricate the $\mathrm{Zn}_{\mathrm{x}} \mathrm{Cd}_{1-\mathrm{x}} \mathrm{S}$ thin films are shown in Table 1 in terms of the nominal concentrations in the deposition solution. The substrate temperature was regulated at $\left(400 \pm 20^{\circ} \mathrm{C}\right)$ during the deposition process using a resistive heater and a thermocouple. Glass substrates were prepared by cutting $(2.5 \times 2.5) \mathrm{cm}^{2}$ pieces and cleaning them by water and they were placed in the microwave until we used them. In order to spray the solution onto the substrate using an ultrasonic atomizer,

nitrogen (N2) Was used as the carrier gas at a pressure of 3 bar with a deposition rate of $3 \mathrm{~cm}^{3} / \mathrm{min}$ during the deposition process. At the end of the spraying process, nitrogen (N2) was flowed onto the thin films formed on the glass substrate for $3 \mathrm{~min}$ in order to dry them. They were then cooled down naturally to room temperature .

flowed onto the thin films formed on the glass substrate for $3 \mathrm{~min}$ in order to dry them . Films thickness was determined by a multiple beam interferometry (Fizeau fringes in reflection). The films were characterized by $X$-ray diffraction technique using (Philips X-ray diffractometer) with CuKa radiation with wavelength (1.5406) $A^{\circ}$. A ( UV-160A UV-visible recording) spectrophotometer supplied by Japanese company (Shimadzu) was used to record the optical absorbance and transmittance spectra of $Z_{n} \mathrm{Cd}_{1-x} \mathrm{~S}$ thin films at wavelength range (480-1100) nm .Surface morphology of the films were studied by using (CSPM AA3000) Atomic Force Microscope ( AFM ) supply by Angstrom Company .

Table 1Solution used for the production of $\mathrm{Zn}_{x} \mathrm{Cd}_{1-x}$ Sthijn films

\begin{tabular}{|c|c|c|c|}
\hline $\begin{array}{c}\text { NominalCompositiono } \\
f \mathrm{Zn}_{x} \mathrm{Cd} 1-x \mathrm{~S}\end{array}$ & $\begin{array}{c}\mathrm{CdCl}_{2}(0.1) \\
(\mathrm{ml})\end{array}$ & $\begin{array}{c}\mathrm{ZnCl} 2(0.1) \\
(\mathrm{ml})\end{array}$ & $\mathrm{H}_{2} \mathrm{NCSNH}_{2}(0.1)(\mathrm{ml})$ \\
\hline 0.0 & 25 & - & 25 \\
0.25 & 18.75 & 6.25 & 25 \\
0.5 & 12.5 & 12.5 & 25 \\
0.75 & 6.25 & 18.75 & 25 \\
1 & - & 25 & 25 \\
\hline
\end{tabular}

\section{Result and discussion:}

\subsection{Structural properties:}

The X-ray diffraction patterns of $\mathrm{Zn}_{\mathrm{x}} \mathrm{Cd}_{1-\mathrm{x}} \mathrm{S}$ thin films where $\mathrm{x}$ equal $(0,0.25,0.5,0.75 \& 1)$ deposited by spray pyrolysis method on glass substrate at R.T with thickness (500) nm are shown in Fig. (1). The XRD patterns for all cases reveal polycrystalline in nature for as-deposited films having the main diffraction peak corresponding to the reflection from (002) plane. The diffraction peaks for (002) are located at $(27.07,27.37,27.76,28.06,28.55)$ for $X$ equal $(0,0.25,0.5,0.75 .1)$ respectively ., therefore it is clear that there is a shift toward higher value of $2 \theta$ when composition $(x)$ change from 0 to 1 .

As compared with ASTM cards, all films exhibit pure hexagonal structure and our results agree with [8]-[9]-[10]-[11][12]-[13]-[14]-[15] . The X-ray peak corresponding to (002) reflection is observed in all cases which represents the 
preferential orientation in $Z \mathrm{Zn}_{\mathrm{x}} \mathrm{Cd}_{1-\mathrm{x}} \mathrm{S}$ films. The intense and sharp peaks in the XRD pattern reveal the good crystallinity of the thin films and confirm the stoichiometric nature of $Z_{x} \mathrm{Cd}_{1-x} S$ thin films.

The preferential orientation (002) in $\mathrm{Zn}_{\mathrm{x}} \mathrm{Cd}_{1-\mathrm{x}} \mathrm{S}$ thin films where $\mathrm{x}=0$ (CdS film) it was reported for thermal vacuum evaporated [16] - [17] - [18] - [19] while it was reported for chemical bathed[20]-[21]. Whereas for $x$ equal to 0.5 and for $x=0.7$ has been also reported for chemical deposited [22], [23] Finally for $x=1$ (ZnS film) the preferential orientation (002) was reported for development technology solution [24] while it was reported for Chemical decomposition[25] . Table (2) illustrates bragg's angles, inter planers spacing, relative intensities, miller indices, and lattice constants of $Z n_{x} C d_{1}$. ${ }_{x} S$ thin films.

The diffraction peaks for $(002)$ are located at $27.07^{\circ}, 27.37^{\circ}, 27.76,28.06^{\circ}$ and $28.55^{\circ}$ for $x$ equal

$0,0.25,0.5,0.75 \& 1)$ respectively, therefore it is clear that there is a shift toward higher value of $2 \theta$ when composition $(\mathrm{x})$ change from 0 to 1 .This shifting has been reported Rehana Zia [14]. This shifting in the peak position with increasing composition $(x)$ suggests that the lattice constants increase with the increasing in Zn concentration as listed in table (2) and calculated from the following equation [26] :

$$
\frac{1}{d^{2}}=\frac{4}{a}\left[\frac{h^{2}+h k+k^{2}}{a^{2}}\right]+\frac{\mathbb{d}^{2}}{c^{2}}
$$

Where $, d:$ is the interplaner distance. $h k l:$ miller indices $, a_{n} c:$ lattice constants.

The calculated values of lattice constants for in $\mathrm{Zn}_{\mathrm{x}} \mathrm{Cd}_{1-\mathrm{x}} \mathrm{S}$ thin films are in good agreement with ASTM data. Similar results have been reported by Ghoneim [13].

It is clear from XRD patterns of in $\mathrm{Zn}_{\mathrm{x}} \mathrm{Cd}_{1-\mathrm{x}} \mathrm{S}$ thin films, that the full width at half maximum (FWHM) decreases with the increasing of $\mathrm{Zn}$ concentration in these films. This decreasing in (FWHM) indicates an increasing in the grain size of in $\mathrm{Zn}_{\mathrm{x}} \mathrm{Cd}_{1-\mathrm{x}} \mathrm{S}$ thin films as given in table (3) according to Scherrer's formula where the relation between the grain size (D) and (FWHM) is reversal as follows [27]:

$$
D=\frac{0.9 \pi}{\beta \cos \theta}
$$

Where,$\beta x$ is the full width at half maximum (FWHM) in radian and $\lambda \approx$ is the $\mathrm{X}$-ray wavelength $\left(1.5406 \mathrm{~A}^{\circ}\right)$.

The increasing in the grain size with increasing in the $\mathrm{Zn}$ concentration had been also reported for chemical path deposition [28]-[21].
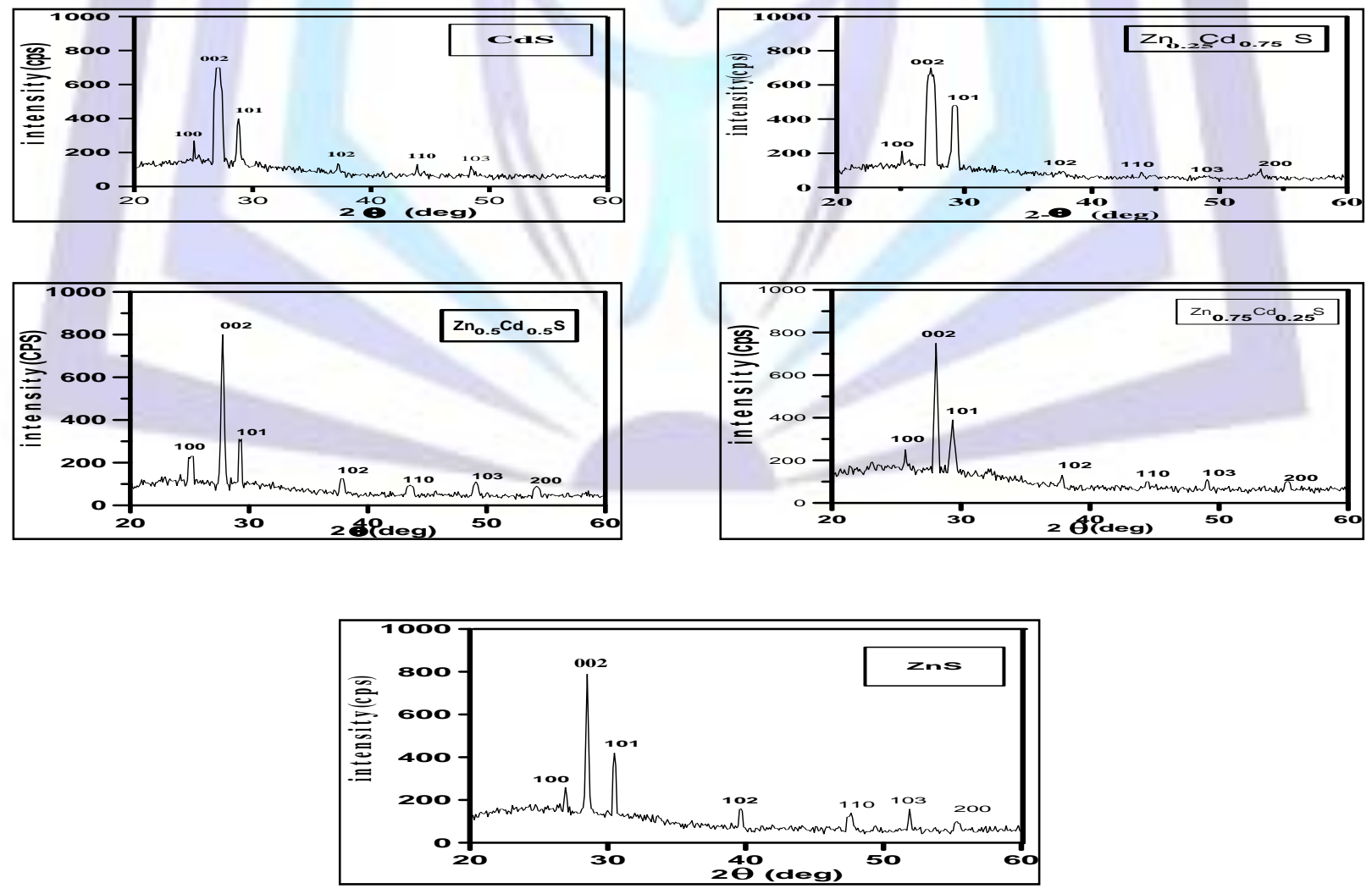

Fig1 X-ray diffractograms of thin film for different concentratio 
Table (2)the structural parameters of $\mathrm{Zn}_{\mathrm{x}} \mathrm{Cd}_{1-\mathrm{x}} \mathrm{S}$ thin films

\begin{tabular}{|c|c|c|c|c|c|}
\hline thin film & $2 \Phi$ & $d(\exp )$ & $\mathrm{d}(\mathrm{ASTM})$ & Hkl & $a(n m)$ \\
\hline \multirow[t]{6}{*}{ CdS } & 25 & 0.3565 & 0.358 & 100 & 0.4116 \\
\hline & 27.0751 & 0.329 & 0.337 & 002 & - \\
\hline & 28.753 & 0.310 & 0.316 & 101 & 0.405 \\
\hline & 37.2412 & 0.241 & 0.245 & 102 & 0.408 \\
\hline & 43.8541 & 0.206 & 0.2068 & 110 & 0.409 \\
\hline & 48.3943 & 0.1879 & 0.1898 & 103 & 0.42 \\
\hline \multirow[t]{6}{*}{$\mathrm{Zn}_{0.25} \mathrm{Cd}_{1-0.25} \mathrm{~S}$} & 25.1011 & 0.3543 & 0.3542 & 100 & 0.375 \\
\hline & 27.3712 & 0.325 & 0.325 & 002 & - \\
\hline & 29.1478 & 0.3056 & 0.3054 & 101 & 0.399 \\
\hline & 37.4386 & 0.239 & 0.235 & 102 & 0.407 \\
\hline & 43.8541 & 0.2062 & 0.2059 & 110 & 0.412 \\
\hline & 54.2306 & 0.17187 & 0.1718 & 200 & 0.3969 \\
\hline \multirow[t]{7}{*}{$\mathrm{Zn}_{0.5} \mathrm{Cd}_{1-0.5} \mathrm{~S}$} & 25.198 & 0.353 & & 100 & 0.407 \\
\hline & 27.766 & 0.321 & & 002 & - \\
\hline & 29.2465 & 0.305 & & 101 & 0.4 \\
\hline & 37.8334 & 0.2375 & & 102 & 0.407 \\
\hline & 43.5581 & 0.2069 & & 110 & 0.413 \\
\hline & 49.0852 & 0.1854 & & 103 & 0.48 \\
\hline & 54.2176 & 0.1689 & & 200 & 0.39 \\
\hline \multirow[t]{7}{*}{$\mathrm{Zn}_{0.75} \mathrm{Cd}_{1-0.75} \mathrm{~S}$} & 25.6933 & 0.346 & & 100 & 0.404 \\
\hline & 28.0621 & 0.3176 & & 002 & - \\
\hline & 29.3452 & 0.304 & & 101 & 0.4015 \\
\hline & 37.8334 & 0.2375 & & 102 & 0.413 \\
\hline & 44.4463 & 0.2037 & & 110 & 0.407 \\
\hline & 49.0852 & 0.1854 & & 103 & 0.443 \\
\hline & 55.3033 & 0.166 & & 200 & 0.383 \\
\hline \multirow[t]{7}{*}{$\mathrm{ZnS}$} & 26.8777 & 0.3313 & 0.3309 & 100 & 0.382 \\
\hline & 28.5556 & 0.3122 & 0.3128 & 002 & - \\
\hline & 30.4309 & 0.2934 & 0.2925 & 101 & 0.383 \\
\hline & 39.61 & 0.2272 & 0.2273 & 102 & 0.3825 \\
\hline & 47.4073 & 0.1915 & 0.1911 & 110 & 0.383 \\
\hline & 51.8488 & 0.1763 & 0.1764 & 103 & 0.3829 \\
\hline & 55.3033 & 0.1659 & 0.1661 & 200 & 0.383 \\
\hline
\end{tabular}

he dislocation density $(\delta)$ of in $\mathrm{Zn}_{\mathrm{x}} \mathrm{Cd}_{1-\mathrm{x}} \mathrm{S}$ thin films which defined as the length of dislocation lines per unit volume of the crystal was calculated from this equation [29]: 


$$
\delta=\frac{1}{\mathrm{D}^{2}}
$$

The values of the dislocation density of in $Z_{x} \mathrm{Cd}_{1-x} S$ thin films are given in table (3). It is evident from this table that the dislocation density of in $\mathrm{Zn}_{\mathrm{x}} \mathrm{Cd}_{1-\mathrm{x}} \mathrm{S}$ thin films decreases with increasing in $\mathrm{Zn}$ concentration which can be also deduced from the increasing in the grain size where the dislocation density is proportion reversely with the square of the grain size according to eq.(3). This decreasing in the dislocation density indicates an improvement in the crystallinity of in $\mathrm{Zn}_{\mathrm{x}} \mathrm{Cd}_{1}$. ${ }_{x} \mathrm{~S}$ thin films and their homogeneity as increasing in $\mathrm{Zn}$ concentration .

The strain ( $\bar{\xi})$ developed in in $\mathrm{Zn}_{x} \mathrm{Cd}_{1-\mathrm{x}} \mathrm{S}$ thin films can calculated from the relation [30] :

$$
\xi=\frac{\beta \cos \theta}{4}
$$

The origin of strain is related to lattice misfit which in turn depends upon the growing condition of the films [31] . The values of the strain of in $Z_{x} \mathrm{Cd}_{1-x} S$ thin films are given in table (3). It is clear from this table that the strain in in $\mathrm{Zn}_{\mathrm{x}} \mathrm{Cd}{ }_{1-\mathrm{x}} \mathrm{S}$ thin films decreases with increasing in $\mathrm{Zn}$ concentration which can be also deduced from the increasing in the grain size , where the decreasing in the strain and the dislocation density with the increasing in the grain size is a well-known phenomenon [32]. In polycrystalline films, the dislocated atoms occupy the regions near the grain boundary . Due to large number of grain boundaries and short distance between them, the intrinsic strains are always associated with such interface . The increasing in the grain size causing reduction in the number of grain boundaries and that leads a reduction in the intrinsic strains associated with the grain boundaries interface

Table 3: variation of the full width at half maximum, grain size, dislocation density and no.of crystals of $Z_{x} \mathrm{Cd}_{1-x} S_{t h i n f i l m s}$ with composition $(\mathrm{x})$.

\begin{tabular}{|l|c|c|c|}
\hline Thin film & $\begin{array}{l}\text { Grain size } \\
(\mathrm{nm})\end{array}$ & $\begin{array}{c}\delta \\
\left(\text { line } / \mathrm{m}^{2}\right)_{*}\end{array}$ & $\begin{array}{c}\mathrm{N}_{\circ} \\
0^{-4} \mathrm{~m}^{-2}\end{array}$ \\
\hline CdS & 37.397 & 7.15 & 3.82 \\
\hline $\mathrm{Zn}_{0.25} \mathrm{Cd}_{1-0.25} \mathrm{~S}$ & 37.13 & 7.25 & 3.9 \\
\hline $\mathrm{Zn}_{0.5} \mathrm{Cd}_{1-0.5} \mathrm{~S}$ & 47.02 & 4.52 & 1.92 \\
\hline $\mathrm{Zn}{ }_{0.75} \mathrm{Cd}_{1-0.75} \mathrm{~S}$ & 46.805 & 4.56 & 1.9 \\
\hline $\mathrm{ZnS}$ & 46.902 & 4.54 & 1.93 \\
\hline
\end{tabular}

\section{Optical properties}

The transmittance spectrum of $\mathrm{Zn}_{x} \mathrm{Cd}_{1-x} \mathrm{~S}$ thin films where $\mathrm{x}$ equal $(0,0.25,0.5,0.75,1)$ are shown in Fig.(2). It is clear from the figure that the transmittance increases with increasing in $\mathrm{Zn}$ concentration which can be also deduced from the changing in the films' colure. This changing in the films' colure was also mentioned by Chaudhari et al. [33] . Also our results agree with Nadeem et al. [34] who found that with increasing in $\mathrm{Zn}$ concentration from 0 to 1 the transmittance of $\mathrm{Zn}_{\mathrm{x}} \mathrm{Cd}_{1-\mathrm{x}} \mathrm{S}$ thin films increases. Also it is clear that the transmittance of $\mathrm{Zn}_{\mathrm{x}} \mathrm{Cd}_{1-\mathrm{x}} \mathrm{S}$ thin films changes from $\approx 70 \%$ to $\approx 90$ $\%$ and this is consider a wide range which can be useful in different application like optical filters and that agree with Kumar[20] . In addition the variation of the transmittance of $\mathrm{Zn}_{\mathrm{x}} \mathrm{Cd}_{1-\mathrm{x}} \mathrm{S}$ thin films with the wavelength is very important because this variation will limit the transmitted wavelengths which play an important role in determination the category/type of the optical filters. The absorbance spectrums of $Z n_{x} C d_{1-x} S$ thin films where $x$ equal $(0,0.25,0.5,0.75, \& 1)$ are shown in Fig. (3). It is clear that as the $\mathrm{Zn}$ concentration increases the absorbance of $\mathrm{Zn}_{x} C \mathrm{~d}_{1-\mathrm{x}} \mathrm{S}$ thin films is decreased. This decreasing in the absorbance is attributed to the decreasing of $\mathrm{Cd}$ concentration which results in an decrease of the depth of donor levels and these levels will be available for the photons to be absorbed therefore the absorbance of $\mathrm{Zn}_{x} \mathrm{Cd}_{1-\mathrm{x}} \mathrm{S}$ thin films will decrease with increasing in $\mathrm{Zn}$ concentration. As well as from the same figure , it can be seen that the absorption edge shifts to the lower wavelengths as the $\mathrm{Zn}$ concentration increased and takes the values $506 \mathrm{~nm}, 496 \mathrm{~nm}, 458 \mathrm{~nm}, 386 \mathrm{~nm}$ and $364 \mathrm{~nm}$ for $x$ equal $0,0.25,0.5,0.75$ and 1 respectively. This shifting in the absorption edge was also mentioned by [15]-[23]. From this shifting in the absorption edge it can be deduced that the energy gap of $Z n_{x} C d_{1-x} S$ thin films will increases with increasing $\mathrm{Zn}$ concentrations. 


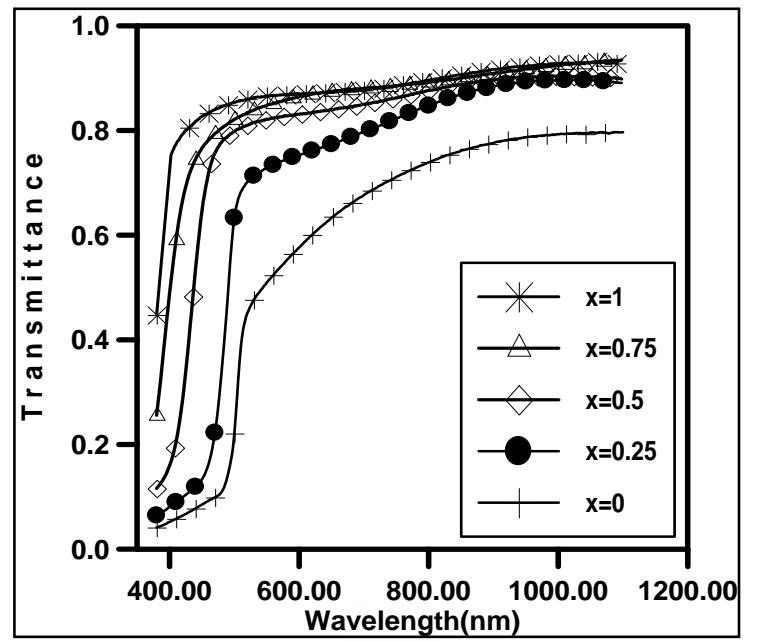

Fig(2)Transmittance spectrums of $\mathrm{Zn}_{\mathrm{x}} \mathrm{Cd}_{1-\mathrm{x}} \mathrm{S}$ thin films

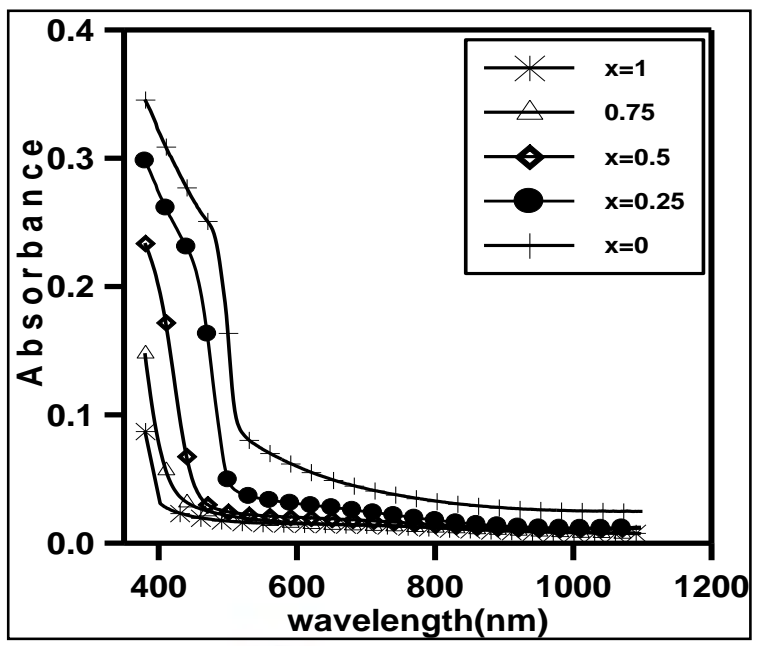

Fig(3) absorbance spectrums of $Z n_{x} C_{1-x} S$ thin films

The optical energy gap values $\left(E_{g}\right)$ for $\mathrm{CdSe}_{x} \mathrm{~S}_{1-\mathrm{x}}$ thin films prepared by thermal evaporation method have been determined from the region of the high absorption at the fundamental absorption edge of these films by using Tauc equation [35]:

$$
\alpha \mathrm{hu}=\mathrm{B}_{0}\left(\mathrm{hu}-\mathrm{E}_{\mathrm{g}}\right)^{\mathrm{r}}
$$

Where,$\alpha$ is the absorption coefficient, ho: is the incident photon energy in $\mathrm{eV}, \mathrm{B}_{0} \times$ is a constant depends on the nature of the material (properties of its valence and conduction band) [36] and $r$ is a constant depends on the nature of the transition between the top of the valence band and bottom of the conduction band [37] .

This equation is used to find the type of the optical transition by plotting the relations $(\alpha h u)^{2},(\alpha h u)^{2 / 3},(\alpha h u)^{1 / 2}$ and $(\alpha h u)^{1 / 3}$ versus photon energy (hu) and select the optimum linear part. It is found that the first relation yields linear dependence, which describes the allowed direct transition, then $E_{g}$ was determined by the extrapolation of the portion at $(\alpha=0)$ as shown in Fig.(4). It is clear that the optical energy gap for $\mathrm{Zn}_{x} \mathrm{Cd}_{1-\mathrm{x}} \mathrm{S}$ thin films increases as the $\mathrm{Zn}$ concentration in the films increased. This is attributed to the decreasing of $\mathrm{Cd}$ concentration which results increase of the depth of donor levels associated which in turn causing a increasein the optical energy gap for $\mathrm{Zn}_{\mathrm{x}} \mathrm{Cd}_{1-\mathrm{x}} \mathrm{S}$

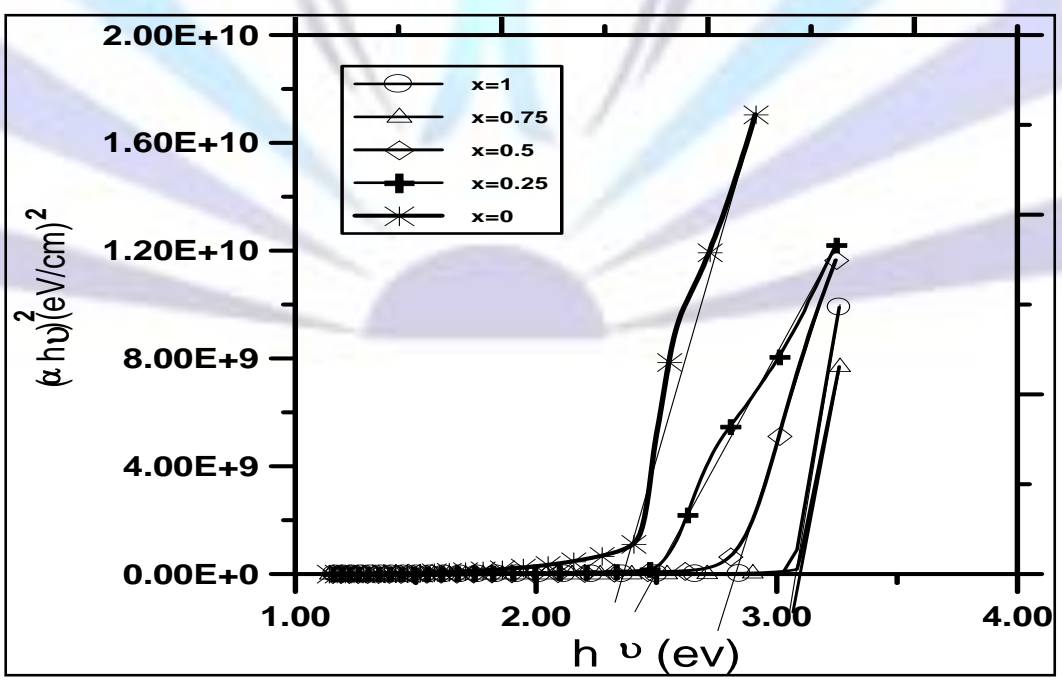

Fig (4 )energy gap of $\mathrm{Zn}_{\mathrm{x}} \mathrm{Cd}_{1-\mathrm{x}} \mathrm{S}$ thin film for different concentration .

thin films. This shifting and increasing in the optical energy gap have been also reported for Martin et.al. [23].The optical energy gap values for $\mathrm{Zn}_{\mathrm{x}} \mathrm{Cd}_{1-\mathrm{x}} \mathrm{S}$ thin films were $2.45 \mathrm{eV}, 2.5 \mathrm{eV}, 2.7 \mathrm{eV}, 3.2$ and $3.43 \mathrm{eV}$ for $\mathrm{x}$ equal $(0,0.25,0.5,0.75$ \& 1) respectively as shown in table 4 . The obtained values of the optical energy gap match well with the reported values of CdS [38]-[39][40] and Zns [34]-[41], the other composition have in between values 
Table 4.Comparison of band gap, energy wavelength of ZnxCd1-xSfilm

\begin{tabular}{|c|c|c|}
\hline $\mathrm{X}=$ & $\mathrm{Eg}(\mathrm{ev})$ & $\lambda(\mathrm{nm})$ \\
\hline 0 & 2.4 & 516 \\
\hline 0.25 & 2.5 & 496 \\
\hline 0.5 & & \\
\hline 0.75 & 2.8 & 443 \\
0.75 & 3.15 & 394 \\
\hline 1 & & \\
\hline & \multicolumn{2}{|c|}{3.1} \\
\hline
\end{tabular}

Chemical spray pyrolysis technique can be successfully employed for the deposition of uniform morphologist and polycrystalline $\mathrm{Zn}_{\mathrm{x}} \mathrm{Cd}_{1-\mathrm{x}} \mathrm{S}$ thin films with hexagonal phase at R.T. The increasing of $\mathrm{Zn}$ concentration in these films has improved the crystallinity of the films and their homogeneity because the decreasing in the strain and the dislocation density with the increasing in the grain size according to the increasing of Se concentration. Morphological studied indicates that surface roughness decreases with increasing in $Z n$ concentration . Optical studied indicates that $Z n_{x} C d_{1-x} S$ thin films exhibit direct band gap which is strongly depends on the $\mathrm{Zn}$ concentration almost cover the entire visible spectral that makes these films are suitable for optoelectronic devices especially for solar cell and optical filte

\section{Reference}

[1] Ortega Borges R, Lincot D and Vedel J 1992 Paper presented at11th European photovoltaic solar energy conference, Montreaux

[2] Orient Tom 1994 J. Electrochem. Soc. 1411320.

[3] Singh R. S. , and Bhushan ,S.,2010, Structural and optical studies of chemically deposited CdS-Se films , Journal of Non-Oxide Glasses Vol. 2, No 3, p. 135-141.

[4] Singh R. S. and Bhushan ,S.,2009, Structural and optical studies of chemically deposited Cd(S-Se ): $\mathrm{CdCl}_{2}, \mathrm{Sm} \mathrm{films}$ Bull Mater. Sci Vol. 32 , No 2 , p. $125-133$.

[5] Murali , K. R., Elango , P., Andavan,P., and K. Venkatachalam ,2008, Preparation of CdS ${ }_{x}$ Se $_{1-x}$ films by brush plating technique and their characteristics, Journal of Materials Science: Materials in Electronics, Vol. 19, No. 3, p. 289293.

[6] Chate, P. A. , Sathe, D. J., and Hankare, P. P.,2011, Electrical and crystallographic properties of nanocrystalline

$\mathrm{CdSe}_{0.5} \mathrm{~S}_{0.5}$ composite thin films deposited by dip method, Journal of Materials Science: Materials in Electronics , Vol. 22, No. 2 , p. $111-115$

[7] T.D.Dzhafarov, Formation of CdZnS thin film by Zn diffusion, Yildiz Technical University Istanbul ,Turkey(2010).

[8] Makadsi,M. Nada, K., Lamia K. 2011, Optical Investigations of CdSe1-x Tex Thin Films, Baghdad Science Journal, Vol.8(1),pp:123-133.

[9] Metin Bedir, Refik Kayali and Mustafa Oztas "Effect of the Zn concentration on the characteristic

parameters $\left(\mathrm{Zn}_{\mathrm{x}} \mathrm{Cd}_{1-\mathrm{x}} \mathrm{S}\right)$ films developed by spraying phyrolysis method under the Nitrogen Atmosphere" Turk $\mathrm{J}$ Phys 26(2002) pp.121-126.

[10] T.Prem Kumar ,K. Sankaranarayanan”Tunability of structural ,surface texture ,compositional and optical properties of ( CdZnS) thin film by photo assisted chemical bath deposition echnique"Chalcogenide Letters , Vol .6 , No .11(2009) p617-622.

[11] . Ayush Khare "Effects of the Zn concentration on Electro-optical properties of $\mathrm{Zn}_{\mathrm{x}} \mathrm{Cd}_{1-\mathrm{x}} \mathrm{S}$ films"Chalcogenide Letters Vol.6,N0.12(2010) P.661-671.

[12] Asogwa, P.U.,2010, "Variation of optical properties with post deposition annealing chemically deposited CdZnS thin films" Chalcogenide Letters Vol.7,No.8, p501-508 . 
[13] .D.Ghoneim "influence of zinc on optical ,Electrical and structural properties of $\left(Z n_{x} C d_{1-x} S\right)$ films"Chalcogenide Letters Vol.7,N0.6(2010)p413-422 .

[14] -Rehana Zia "Preparation and Characterization of Thin Film Polycrystalline Solar Cells "Doctors thesis, Department of Physics / University Lahore college for women (2008).

[15] . Maysa Tayseer "proparation and Enhancement of( Cds/ZnS) thin film for photovoltaic purposes "Thesis of Master/An-Najah National University ,Nablus(2010).

[16] Zhibing He, Gaoling Zhao , Wenjian Weng, Piyi Du, Ge Shen and Gaorong Han , The difference between the transverse and in-plane resistivity of vacuum evaporated cadmium sulfide (CdS) thin films, Vacuum, Vol. 79, Issues 1-2 , 8 July (2005), p.14-18

[17] A. Ashour, The physical characteristics of $\mathrm{Cu}_{2} \mathrm{~S} / \mathrm{CdS}$ thin-film solar cell , Journal of Optoelectronics and Advanced Materials Vol. 8, No. 4, August (2006), p. 1447 - 1451.

[18] Ion , L. Enculescu , I. Iftimie ,S., Ghenescu , V., Tazlaoanu , C. Besleaga, Mitran , T. L., Antohe , V. A. Gugiu and M. M. Antohe ,S.,2010,Effect of proton irradiation on the spectral performance of photovoltaic cells based on CdS/CdTe thin films, Chalcogenide Letters Vol .7, No. 8 , p. 521-530.

[19] Z.R. Khan , M. Zulfequar and M.S. Khan, Effect of thickness on structural and optical properties of thermally evaporated cadmium sulfide polycrystalline thin films , Chalcogenide Letters Vol. 7, No. 6, June (2010) , p. $431-438$.

[20] .T.Prem Kumar ,S. Saravana Kumar and,K.Sankaranarayanan"Effect of annealing on the surface and band gap alignment of (CdZnS) thin films" Applied surface Science,95 (2010) 235-241.

[21]. Zoubeıda Khefachaa, Zohra Benzartib and Mohamed Mnaria,"Electrical and optical properties of $\mathrm{Cd}_{1-x} \mathrm{Zn}_{\mathrm{x}} \mathrm{S}$ $(0<X<0.18)$ grown by chemical bath deposition"Jornal of Crystal Growth 260(2004) p400-409.

[22]. .T.Prem Kumar ,K. Sankaranarayanan"Tunability of structural ,surface texture ,compositional and optical properties of( $\mathrm{CdZnS}$ ) thin film by photo assisted chemical bath deposition technique"Chalcogenide Letters, Vol .6 , No .11(2009) p617-622.

[23]. Metin Bedir, Refik Kayali and Mustafa Oztas,2002, "Effect of the Zn concentration on the characteristic parameters $\left(\mathrm{Zn}_{\mathrm{x}} \mathrm{Cd}_{1-\mathrm{x}} \mathrm{S}\right)$ films developed by spraying phyrolysis method under the Nitrogen Atmosphere" Turk $\mathrm{J}$ Phys 26, pp.121-126.

[24].Appl,J. "Grown Thin Films of ZnxCd1-xS Solution on Studies " [24]. G. K. Padam, G. L. Malhotra and S. U. M. Rao Phys, V. 63, No.3, PP. 770-774.

[25]. M.Celaettin Baykul,Nilgun Orhan ,2010,"Band alignment of $\left(\mathrm{Cd}_{1-\mathrm{x}} \mathrm{Zn} \mathrm{n}_{\mathrm{x}} \mathrm{S}\right)$ produced by spay pyrolasis method "Thin Solid Films 518,p1925-1928.

[26]. ] K. Sivaramamoorthy, S. Asath Bahadur , M. Kottaisamy and K. R. Murali ,2010, Structural, optical and photoconductive properties of electron beam evaporated $\mathrm{CdS}_{x} \mathrm{Se}_{1-\mathrm{x}}$ films , Crystal Research and Technology Vol. 45, Issue 4, p. 414-420

[27] Y. Sitrotin and M. Shaskolskaya, "Fundamental of crystal physics", (Mir publishers, Moscow, 1982).

[28]. . M. Dhanam, B. Kavitha "Influence of tea (complexing agent) on the structural propertiec of CBD ZnS Thin Films" Chalcogenide Letters Vol.6,No.7(2009) P 299-307.

[29] M.M.EL Nahass and A.M.A. EL Barry, Effect of substrate temperature, deposition rate and heat treatment on structural and carrier transport mechanisms of thermal evaporated $\mathrm{p}-\mathrm{Cu}_{2} \mathrm{~S} / \mathrm{n}-\mathrm{CdS}$ heterojunction , Indian Journal of Pure \& Applied Physics Vol. 45, May (2007), p. 465-475.

[30] Z.R. Khan , M. Zulfequar and M.S. Khan, Effect of thickness on structural and optical properties of thermally evaporated cadmium sulfide polycrystalline thin films, Chalcogenide Letters Vol. 7, No. 6, June (2010), p. 431-438

[31]. K. Sarmah, R. Sarma and H. L. Das , Correlative assessment of structural and photoelectrical properties of thermally evaporated CdSe thin films , Journal of Non-Oxide Glasses Vol. 1, No. 2, (2009), p. 143-156

[32]. Suthan Kissinger , N.J., Suthagar , J., Saravana Kumarc, B. Balasubramaniam T.and Perumal , K.,2010,Effect of substrate temperature on the structural and optical properties of nanocrystalline cadmium selenide thin films prepared by electron beam evaporation technique, ACTA PHYSICA POLONICA A, Vol .118, No. 4, p. 623-628

[33]. Chaudhari, J.B., Deshpande, N.G.,. Gudage, Y.G, A. Ghosh, Huse and Ramphal Sharma V.B.,2008, Studies on growth and characterization of ternary $\mathrm{CdS}_{1-\mathrm{x}} \mathrm{Se}_{\mathrm{x}}$ alloy thin films deposited by chemical bath deposition technique , Applied Surface Science , Vol.254, p. 6810-6816.

[34]. Nadeem, M.Y.,waqas,A.,2000,"Optical Properties of ZnS Thin Films"Turk.j.phy V.24,pp.651-659.

[35] Mott N. F., and Davis, E. A.,1979, "Electronic Processes in Non-Crystalline Materials",(2 ${ }^{\text {nd }}$, Clarendon Press, oxford,

[36] Kasap , S. O.,2002, "Principle of electronic materials and devices ", (Snded, McGraw-Hill , New York ,. 
[37] Z.R. Khan , M. Zulfequar and M.S. Khan, Effect of thickness on structural and optical properties of thermally evaporated cadmium sulfide polycrystalline thin films, Chalcogenide Letters Vol. 7, No. 6, June (2010) , p. 431 -438.

[38]. Yadav, A.A. and Masumdar , E.U.,2010,Optical and electrical transport properties of spray deposited $\mathrm{CdS}_{1-x} \mathrm{Se}_{\mathrm{x}}$ thin films , Journal of Alloys and Compounds Vol. 505 , p. 787-792 .

[39]. ] Rusu, M. Rumberg, A. Schuler, S. Nishiwaki, R. Würz, S.M. Babu, M. Dziedzina, KelchC., S. Siebentritt, R. Klenk, Th. Schedel-Niedrig, M.Ch. Lux-Steiner ,2003, Optimization of the CBD CdS deposition parameters for $\mathrm{ZnO} / \mathrm{CdS} / \mathrm{CuGaSe}_{2} / \mathrm{Mo}$ solar cells , Journal of Physics and Chemistry of Solids Vol. 64 , (2003), p.1849-1853.

[40].Abdullah Serhan AL-Shammari,2005, "Preparation and characterization of chlorine doped cadmium sulphide (CdS,CL)thin film and their application in solar cells "Thesis of Master, King Saud University, college of Science.

[41]. Dedova,T., Krunks, M., Volobujeva and I. O.,2004, Department of Materials Science, "Tallinn University of Technology", Estonia.

\section{Authors' information}

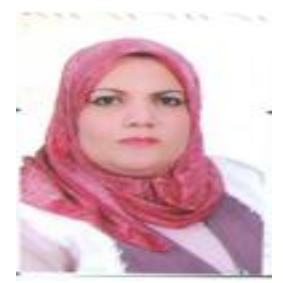

Professor Nada Khdair Abbas, Ph.D. in the Department of Physics, College of Science for Women, University of Baghdad .She had awarded the B.Sc. degree from the department of physics in 1986, M.Sc. in 1995 and Ph.D. in 2000. Teaching Students of under and post graduate, Chief of solid and materials group, Chairman department of physics, Committee Chairman promotions in the college of Science for women. She interested with research about Nanotechnology, the thinfilms and their use in solar cells and detectors.

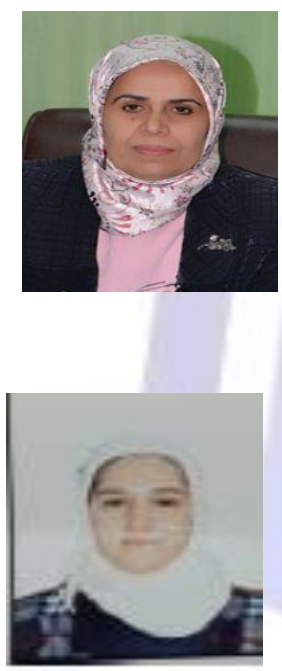

Prof. Dr. Ahlam M. Farhan : Acting Dean of College of Science for Women Ph.D. in the Department of Chemistry, College of Science for Women, University of Baghdad She had awarded the B.Sc. degree of from the department of Chemistry in 1985,, M.Sc. in 1995 and Ph.D. in 2000. Teaching Students of under and post graduate.
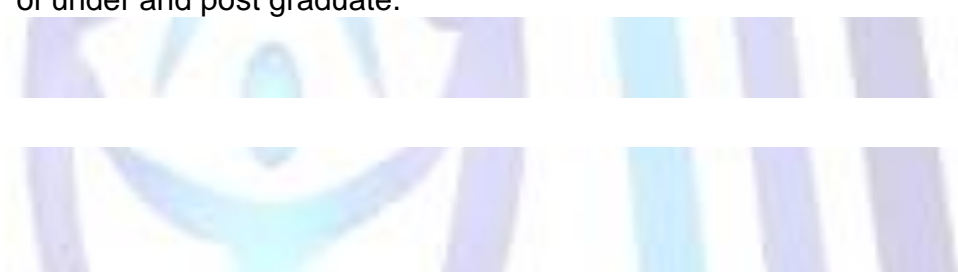

Neean F.Mageed: was born in Baghdad in 1989 .She had awarded the B.Sc. degree from the department of physics, College of Science for Women, University of Baghdad in the year 2009/2010. She works as assistant of physicist in college of science for women, physics department, Baghdad University. She interest in field of solid materials and nanotechnology research 